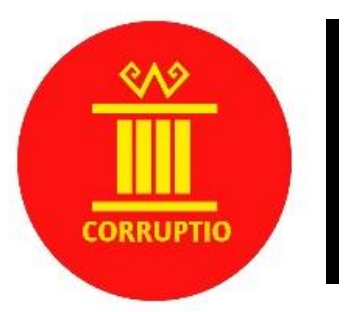

CORRUPTIO

Fakultas Hukum, Universitas Lampung, Bandar Lampung, Lampung, Indonesia. http://jurnal.fh.unila.ac.id/index.php/corruptio

Volume 2 Issue 2, July - December 2021. PP: 99-112

P-ISSN: 2723-2573 E-ISSN: 2745-9276

\title{
Law Enforcement of Corruption Cases Through a Participatory Society as an Effort to Protect Constitutional Rights
}

\author{
Diya UI Akmal ${ }^{1}$, Pipih Ludia Karsa ${ }^{2}$, Syafrijal Mughni Madda ${ }^{3}$ \\ ${ }^{1}$ Universitas Sultan Ageng Tirtayasa, Indonesia, diyaulakmal@gmail.com \\ ${ }^{2}$ Universitas Sultan Ageng Tirtayasa, Indonesia, pipihludiakarsa@ymail.com \\ ${ }^{3}$ Universitas Sultan Ageng Tirtayasa, Indonesia,syafrijalmm@gmail.com
}

Submitted: Jun 28, 2021; Reviewed: Oct 21, 2021; Accepted: Oct 29, 2021

Abstract

Keywords: Corruption; Protection of

Constitutional Rights; and Participatory

Society.

DOI :

https://doi.org/10.25041/corruptio.v2i2.2368
A participatory society can play an essential role in the prosecution of corruption cases. By providing information on alleged corruption, a participatory community can assist anticorruption institutions so that corruption as an extraordinary crime can be eradicated as a means of enforcing people's constitutional rights. The authors attempt to perceive things by defending constitutional rights from a societal standpoint, a right of citizens who have had their rights violated by acts of corruption. The method used in this research is a normative legal method that refers to the norms in the laws and regulations, court decisions, and social society. The data used is secondary data obtained from various sources with appropriate and relevant topics so that it becomes chaotic in discussing related problems. The community's active role in uncovering corruption cases is part of the obligation to break the chain of corruption and fulfil citizens' rights to enforce the law. The amount of budget allocated for disclosing corruption cases is leading the government to protect citizens' constitutional rights from the threat of corruption. Although the handling is still considered unsuccessful because many cases have not been revealed, the efforts made deserve to be recognised. 


\section{A. Introduction}

The cultural framework of corruption creates a social dimension in which corruption is seen as natural and acceptable. ${ }^{1}$ Corruption is the result of both opportunity and a determination to profit from it. $^{2}$ It's an impediment to economic growth that can severely reduce the effectiveness of capital and productivity on economic growth. ${ }^{3}$ Individuals are forced to choose between obeying the law and following existing social constructions due to differences in moral interpretation and clashes in social relations. ${ }^{4}$ This puts general moral norms in jeopardy in the intelligence community and threatens the nation's long-term viability and future generations. ${ }^{5}$ Government must make continuous efforts to eradicate corruption. Strengthening the anti-corruption character is a preventive measure in the fight against corruption. Its implementation will necessitate additional resources from affiliated institutions, human resources, and efforts to improve the character of anti-corruption individuals. ${ }^{6}$ Eradicating corruption protects citizens' constitutional rights in addition to being a matter of law enforcement. This defense is linked to the defense of human rights.

The desire of the people for order and personal safety leads to the formation of a state. The state creates the rule of law and seeks to properly enforce it as a result of the people's will. Laws are made all the time that govern every aspect of life. Thus law-making organisations must properly form laws and meet the needs of a sense of justice. ${ }^{7}$ Justice is a fundamental right that everyone has in enforcing the law. Although justice is very subjective to each individual is experiencing, justice in the fight against corruption has a broader scope. Cases of corruption committed by specific individuals have permanently harmed and disadvantaged society as a whole. In cases of corruption, community communal justice must be safeguarded. As the primary victims of corruption, the community understandably wishes to fight for their rights alongside elements of state institutions involved in the fight against corruption. As corruption is prevalent throughout the region, the community has the necessary abilities and networks to combat it. ${ }^{8}$ To develop just law enforcement, the state must be able to realise this community participation.

As the largest community organization, the state must be able to protect its people's rights through effective and impartial law enforcement. The exercise of fundamental rights cannot be denied for any reason. Any current issues with eradicating corruption must be addressed as soon as possible. Begin by reforming ineffective legal norms, implementing fair law enforcement, teaching a legal culture to build legal order, and creating space for directly

\footnotetext{
${ }^{1}$ Supeni Anggraeni Mapuasari and Hadi Mahmudah, "Korupsi Berjamaah: Konsensus Sosial Atas Gratifikasi Dan Suap,” Integritas: Jurnal Antikorupsi 4, no. 2 (2018): 159-76, https://doi.org/10.32697/integritas.v4i2.279.

2 Bruce L. Benson, "Corruption in Law Enforcement: One Consequence of 'The Tragedy of the Commons' Arrising with Public Allocation Processes," International Review of Law and Economics 8, no. 1 (1988): 73-84, https://doi.org/10.1016/0144-8188(88)90016-6.

${ }^{3}$ Karla Borja, "Corruption Indicators, Foreign Capital, and Economic Growth in Developing Countries," The Journal of Developing Areas 51, no. 4 (2017): 95-107, https://doi.org/10.1353/jda.2017.0090.

${ }^{4}$ Kanti Pertiwi, "Kesenjangan Dalam Wacana Antikorupsi Di Indonesia: Temuan Dari Literatur Studi Korupsi Kritis," Integritas: Jurnal Antikorupsi 5, no. 2 (2019): 133-50, https://doi.org/10.32697/integritas.v5i2.475.

5 Wicipto Setiadi, "Korupsi Di Indonesia (Penyebab, Bahaya, Hambatan Dan Upaya Pemberantasan, Serta Regulasi)," Jurnal Legislasi Indonesia, accessed April 26, 2021, https://ejurnal.peraturan.go.id/index.php/jli/article/view/234.

${ }_{6}^{6}$ Hikmah Hikmah and Eko Sopoyono, "Kebijakan Formulasi Sanksi Pidana Mati Terhadap Pelaku Tindak Pidana Korupsi Berbasis Nilai Keadilan," Jurnal Pembangunan Hukum Indonesia 1, no. 1 (2019): 78-92, https://doi.org/10.14710/jphi.v1i1.78-92.

7 Retno Mawarini Sukmariningsih, "Penataan Lembaga Negara Mandiri Dalam Struktur Ketatanegaraan Indonesia," Mimbar Hukum - Fakultas Hukum Universitas Gadjah Mada 26, no. 2 (2014): 194-204, https://doi.org/10.22146/jmh.16039.

${ }^{8}$ Epa Kartika, Rizky Nugraha Murnawan, and Agung Budiono, "Peran Masyarakat Sipil Dalam Pemberantasan Korupsi Sektor Sumber Daya Alam," Integritas: Jurnal Antikorupsi 5, no. 2 (2019): 93-106, https://doi.org/10.32697/integritas.v5i2-2.485.
} 
participatory communities. It is hoped that the national legal system will protect people's constitutional rights to the greatest extent possible, particularly in the fight against corruption.

This article is distinct from others that have previously appeared. When analyzing corruption cases from the standpoint of protecting constitutional rights, previous research has tended to focus on protecting the rights of perpetrators. The author attempts to see things from a different perspective by defending constitutional rights from a societal standpoint, a right of citizens whose rights have been violated by corrupt acts. In dealing with this, the community is a vulnerable group. The public can aid in the eradication of corruption by investigating potential acts of corruption committed by associated individuals. The public's participation in law enforcement in corruption cases is hoped to result in broad justice and the protection of the community's constitutional rights.

This study was conducted to determine how people's constitutional rights could be protected, which is also essential in the fight against corruption. The implementation of this protection also allows the general public to assist law enforcement in corruption cases. The discussion will be divided into three parts: law enforcement of corruption cases in Indonesia, legal protection of constitutional rights in the fight against corruption, and participatory society in anti-corruption efforts. The method used is a normative legal method that refers to the norms in the laws and regulations, court decisions, and social society. ${ }^{9}$ The data used is secondary data obtained from various sources with appropriate and relevant topics so that it becomes chaotic in discussing related problems. This writing data collection is through library research with secondary data sources in the form of primary legal materials (laws and regulations), secondary legal materials (books, journals, and papers), and tertiary legal materials (Internet). ${ }^{10}$ The data obtained will be described using words with scientific logic.

\section{B. Discussion}

\section{Law Enforcement of Corruption Cases in Indonesia}

The constitution mandates that the government protect all Indonesians, necessitating the establishment of a fair and constitutional state. ${ }^{11}$ The existing law must be strictly enforced, and everyone must be treated equally before the law. Crime is an urgent public concern that must be remedied to produce harmonious, orderly, and peaceful living as an expression of a peaceful society. Law enforcement is the state's role to safeguard its citizens. ${ }^{12}$ Lawrence M. Friedman ${ }^{13}$ in his theory, "legal system" argues that the success or failure of law enforcement is influenced by three elements in the legal system, including:

a. Legal structure, which includes elements of law enforcers and their respective roles;

b. Legal substance, which encompasses the entire rule of law in a country; and

c. Legal culture, which includes moral attitudes and social values in society.

Law enforcement is the process of enforcing abstract legal norms on actual events. The social meaning of law enforcement can have an impact on society. The system in use cannot be changed at will. The legal system must play both a negative role as a deterrent to crime and a positive role with significant societal implications. This deep meaning can be interpreted as the benefits felt by the community. Soerjono Soekanto argues that law enforcement is an activity that aims to harmonise the relationship of values outlined in the principles that embody the attitude of action as a sequence of final-stage value descriptions to achieve and

\footnotetext{
${ }^{9}$ Zainuddin Ali, Metode Penelitian Hukum (Jakarta: Sinar Grafika, 2011): 105.

${ }^{10}$ Bambang Sunggono, Metodologi Penelitian Hukum (Jakarta: Rajawali Press, 2015):113-114.

${ }^{11}$ See the 4th paragraph of the Preamble and Article 1 paragraph (3) of the 1945 Constitution of the Republic of Indonesia.

12 Vivi Ariyanti, "Kebijakan Penegakan Hukum Dalam Sistem Peradilan Pidana Indonesia," Jurnal Yuridis 6, no. 2 (2019): 33-54, https://doi.org/10.35586/jyur.v6i2.789.

${ }^{13}$ Lawrence M. Friedman, The Legal System: A Social Science Perspective (New York: Russel Sage Foundation, 1975): 14 .
} 
sustain social peace. ${ }^{14}$ As described by Gustav Radbruch, the law enforcement process is an effort to create legal certainty, which ultimately leads to benefit and justice as legal objectives. ${ }^{15}$ Consistent and integrated law enforcement is essential to achieving the pillars of justice. The pillar of justice serves as the primary foundation for community participation in state administration. ${ }^{16}$ This interpretation is a type of people's sovereignty, which is a constitutionally protected right of citizens. The hope will lead to the benefits that the community will receive. The entire community must sense the highest essence of justice and benefit. Law enforcement must be aligned with the legal system that a country has established and implemented.

The legal system has a mechanism that ensures the fair, definite, and firm implementation of regulations and benefits for the maintenance of public order and peace. In criminal law enforcement, the three elements put forward by Friedman are essential to interact with each other. If one of them does not work well, the overall impact will be felt. The implementation of law enforcement is closely related to criminal law because legal subjects, legal objects, and actions committed can be subject to punishment in the form of a conviction. In general, criminal offences in Indonesia have been regulated in a codification of law (code penal), namely the Criminal Code $(K U H P)$ and crimes of an exceptional nature are contained in laws outside the KUHP. One of the special rules relating to criminal acts is a corruption case.

Corruption is a growing and systematic crime, necessitating the establishment of a remarkable institution responsible for the prevention and elimination of corruption. Corruption must be handled seriously since it can harm a country's finances and economy. A law has been enacted to resolve corruption issues, giving the Corruption Eradication Commission $(K P K)$ authority as a legitimate institution to conduct investigations and prosecutions of corruption cases. ${ }^{17}$ The number of cases of corruption disclosed every year is consistently high. The following is presented data of the judicial process on corruption cases in 2019.

Table. 1. Recapitulation of Corruption Case Data in 2019

\begin{tabular}{|c|c|}
\hline Judicial Process & Number of Cases \\
\hline Probe & 142 Cases \\
\hline Investigation & 268 Cases \\
\hline Prosecution & 234 Cases \\
\hline Inkracht Verdict & 142 Cases \\
\hline Execution of Court Decisions & 136 Cases \\
\hline \multicolumn{2}{|c|}{ Source: KPK, “Laporan Tahunan KPK 2019”, p. 124.} \\
\hline
\end{tabular}

According to the data presented above, Indonesia still has many corruption cases. The current law has no deterrent effect on existing corruption cases. The number of corruption cases revealed each year grows. On the one hand, this is a success in upholding the law, but cultural morality is highly problematic. It is difficult to maintain control over the corrupt

\footnotetext{
${ }^{14}$ Soerjono Soekanto, Faktor-Faktor Yang Mempengaruhi Penegakan Hukum (Jakarta: UI Press, 1983): 35.

${ }^{15}$ Muhammad Erwin, Filsafat Hukum Refleksi Kritis Terhadap Hukum (Jakarta: Rajawali, 2013): 123.

${ }^{16}$ Bambang Waluyo, “Optimalisasi Pemberantasan Korupsi Di Indonesia,” Jurnal Yuridis 1, no. 2 (2014): 16982.

${ }^{17}$ See Law Number 19 of 2019 Concerning the Second Amendment to Law Number 30 of 2002 Concerning the Corruption Eradication Commission.
} 
mentality that emerges. Corruption will never be completely eradicated as a result of this entrenched corruption. ${ }^{18}$

Despite being part of the executive power clump, the Constitutional Court specifically noted in its judgement that the KPK is a state institution that is independent and free from the influence of any power. ${ }^{19}$ This also includes the People's Representative Council (DPR) as an institution that creates laws that are not permitted to interfere with the $K P K$ through Act amendments. ${ }^{20}$ Meanwhile, if the DPR wanted to amend the KPK Law, it must strengthen its authority in eradicating corruption rather than weakening its institutions. ${ }^{21}$ So that the KPK's duty of eradicating corruption is free of the interests of specific individuals and groups.

There are five things that law enforcement officers do to gain personal benefits by exploiting existing legal rules, which include: ${ }^{22}$

a. Early on, some investigators took advantage of negotiations with corruptors;

b. Attempts were made not to detain corruption suspects at an early stage;

c. If the case goes to trial, efforts are made to reduce the charges or even obtain an acquittal. Looking at the tendency of judges who are very legalistic, an acquittal can occur. If the indictment is not based on his material actions, the corruptor may be released;

d. Judges rarely give maximum sentences, even in exceptional circumstances such as corruption committed during natural disasters; and

e. When criminals are found guilty, they are given easy access to detention and have a good chance of receiving pardon and remission.

These irresponsible actions endanger the people's rights, which they are entitled to from the state. Society cannot intervene. All law enforcement officers must share a common understanding to uphold justice. Existing legal tools must be fully utilized in dealing with corrupt perpetrators. The professionalism of law enforcement officers must also be improved so that they do not violate existing laws. ${ }^{23}$ Justice can only be enforced if the judicial system is free of bias and any attempt to benefit oneself. Impartiality in the judiciary extends to the suspect and all other stakeholders, including victims, crown witnesses, witnesses and their families, and people in the community with interest in the case.$^{24}$ Currently, the public has the right to participate in law enforcement efforts by reporting any findings of suspicion of corruption. This mechanism is also motivated by public unrest and a strong desire to eliminate corruption.

\section{Legal Protection of Constitutional Rights in the Eradication of Corruption}

Applicable legal rules must exercise the government's authority. Plato coined the term nomoi, which recognised that good state administration must be formed on good governance. Furthermore, Aristotle stated that ruling a country is based on fair thinking (determining

${ }^{18}$ Listiyono Santoso, Dewi Meyriswati, and Ilham Nur Alfian, "Korupsi Dan Mentalitas: Kendala Kultural Dalam Pemberantasan Korupsi Di Indonesia,” Jurnal Masyarakat, Kebudayaan Dan Politik 27, no. 4 (2014): 173-83, https://doi.org/10.20473/mkp.V27I42014.173-183.

${ }^{19}$ See Constitutional Court Decision Number 70/PUU-XVII/2019.

${ }^{20}$ Rizki Ramadani, "Reformulation of Institutional Relationship between the People's Representative Council and the Corruption Eradication Commission," Corruptio 2, no. 1 (2021): 33-44, https://doi.org/10.25041/corruptio.v2i1.2264.

${ }^{21}$ Joko Sriwidodo, "Changes in Corruption Eradication Commission in Legal Sociology Perspective," Corruptio 1, no. 1 (n.d.): 49-62, https://doi.org/10.25041/corruptio.v1i1.2073.

22 Agus Pramono, “Kekuasaan Dan Hukum Dalam Perkuatan Pemberantasan Korupsi,” Jurnal MMH 42, no. 1 (2013): 105-13.

${ }^{23}$ Saldi Isra et al., "Obstruction of Justice in the Effort to Eradicate Corruption in Indonesia," International Journal of Law, Crime, and Justice 51 (2017): 72-83, https://doi.org/10.1016/j.ijlcj.2017.07.001.

${ }^{24}$ Agus Nurudin, "Upholding the Impartiality of Judges in Judicial System," Hasanuddin Law Review 6, no. 1 (2020): 80-88, https://doi.org/10.20956/halrev.v6i1.2268. 
whether a law is good or not). As a result, the rule of law is a manifestation of just law. ${ }^{25}$ The essence of a state of the law is a restriction based on the applicable law. The restriction is also a fundamental principle of democratic constitutionalism. According to Andrew Heywood, constitutionalism can be interpreted as limited to the administration of a country governed by the constitution. According to Richard S. Kay in the introduction to Larry Alexander, constitutionalism focuses on limiting government power. ${ }^{26}$

According to Lord Acton, power tends to corrupts, and absolute power corrupts absolutely. Restrictions based on applicable legal rules must be imposed in the administration of the country. In reality, even when laws are in place, the threat of corruption persists and is a significant source of concern for almost all countries. Corruption is a disease that threatens society's stability and security, democratic values, ethical values, justice, and law enforcement, as well as the long-term viability of sustainable development. ${ }^{27}$

Corruption can endanger the nation's future and turn into a common enemy. Efforts to prevent corruption must be made in various ways, including the establishment of strict legal rules, the implementation of anti-corruption campaigns, and the provision of anti-corruption education. ${ }^{28}$ At last, the assumption that the government cannot implement the principles of good governance develops in society, even though those who commit corruption are simply people who do not think society.

The corruption cases have violated constitutional rights, which also correlate with the community's human rights. In Indonesia, the concept of human rights talks about fundamental human rights and citizens' obligations to comply with laws and regulations. These laws are written in respect for the human rights of others, morals, ethics, and obeying international law regarding human rights, which has been accepted by the Indonesian people and is obligated to defend the country. ${ }^{29}$ The fundamental protection afforded to every citizen by the constitution is the protection of constitutional rights. The linkage between constitutional rights and human rights is based on the concept of the continental European system, which states that human rights are protected as long as they are enshrined in constitutional norms. If human rights are normalised in the constitution, they become citizens' rights that must be recognised. ${ }^{30}$ Constitutional rights violations are most common in underserved communities, whether economically, socially, physically, or minority groups. Constitutional rights are interpreted in light of the nation's goal of protecting the entire Indonesian nation, promoting public welfare, educating the nation's life, and participating in maintaining world order.

25 Badan Pengkajian MPR RI., and Lembaga Penelitian dan Pengabdian Masyarakat, Universitas Jederal Soedirman, SURVEI NASIONAL Evaluasi Pelaksanaan Undang-Undang Dasar Negara Republik Indonesia Tahun 1945. (Badan Pengkajian MPR RI, 2018): 8.

${ }^{26}$ Wahyudi Djafar, "Menegaskan Kembali Komitmen Negara Hukum: Sebuah Catatan Atas Kecenderungan Defisit Negara Hukum Di Indonesia,” Jurnal Konstitusi 7, no. 5 (2010): 151-74.

27 Adib Bahari and Khotibul Umam, KPK: Komisi Pemberantasan Korupsi Dari A Sampai Z. (Yogyakarta: Pustaka Yustisia, 2009): 25.

${ }^{28}$ Santoso, Meyriswati, and Alfian, "Korupsi Dan Mentalitas: Kendala Kultural Dalam Pemberantasan Korupsi Di Indonesia."

${ }_{29}$ Muladi Muladi, Hak Asasi Manusia Hakekat, Konsep Dan Implikasinya Dalam Perspektif Hukum Dan Masyarakat (Bandung: Refika Aditama, 2009): 6.

${ }^{30}$ Max Boli Sabon, Hak Asasi Manusia: Bahan Pendidikan Perguruan Tinggi (Jakarta: Universitas Katolik Indonesia Atma Jaya, 2019): 6. 
Furthermore, the constitutional rights possessed by Indonesian citizens are as follows:

Table. 2. Constitutional Rights of Indonesian Citizens

\begin{tabular}{|c|c|}
\hline $\begin{array}{l}\text { Article in the } \\
\text { Constitution }\end{array}$ & Constitutional Rights of Citizens \\
\hline Article 27 paragraph (1) & $\begin{array}{l}\text { The right to equal position before the law and } \\
\text { government }\end{array}$ \\
\hline Article 27 paragraph (2) & The right to work and a decent living \\
\hline Article 27 paragraph (3) & The right to participate in efforts to defend the state \\
\hline Article 28 & $\begin{array}{l}\text { The right to associate and assemble and express } \\
\text { opinions }\end{array}$ \\
\hline Article 28A-28I & Fulfilment of Human Rights \\
\hline Article 29 paragraph (2) & The right to embrace their respective religions \\
\hline Article 31 paragraph (1) & Right to education \\
\hline $\begin{array}{l}\text { Article } 33 \text { paragraph }(1-2) \\
\text { and Article } 34\end{array}$ & Right to social welfare \\
\hline
\end{tabular}

Source: 1945 Constitution of the Republic of Indonesia.

As a legal state, the state is obligated to provide legal protection for citizens through the establishment of a free and impartial judiciary and the guarantee of human rights and equality before the law. ${ }^{31}$ Equality before the law must include victims as equal parties with equal rights. The state is obligated to implement and fulfil citizens' constitutional rights without exception. In cases of corruption, the state, through related state institutions, must protect these constitutional rights through enforcement of the law. Corruption has violated constitutional rights in economic, social, and cultural rights, which are linked to human rights. The state budget, which should be channeled for community welfare, is being corrupted by corruptors. Even corruption can have an impact on public policies, which will ultimately make people miserable. ${ }^{32}$ As a result, the participation of all parties is required to eradicate corruption and restore people's rights that have been stripped away.

\section{Participatory Society in Efforts to Eradicate Corruption}

People in the social sphere seem to see corruption as a legal issue that must be resolved legally. Corruption is also fueled by a cultural mentality and beliefs that prioritise wealth and the throne. Corruption tends to be carried out to satisfy power over property without regard for the rights of the people. ${ }^{33}$ The corruption eradication in Indonesia faces its own set of challenges in terms of implementation. Everyone has the potential to be corrupt. In the context of state administration, a person can be accused of corruption if there is a loss to the state, regardless of whether or not the suspect committed the action. As a result, corruption becomes a vicious circle that is difficult to break. On the other hand, strict instruments are required to avoid punishing an innocent person.

The dilemma of eradicating corruption is a type of legal protection of citizens' constitutional rights. According to Satjipto Raharjo ${ }^{34}$, the purpose of legal protection is to

\footnotetext{
31 A. Ubaedillah, Pancasila Demokrasi Dan Pencegahan Korupsi (Jakarta: Prenadamedia Group, 2015): 92.

${ }^{32}$ Habib Shulton Asnawi, "Membongkar Paradigma Positivisme Hukum Dalam Pemberantasan Korupsi Di Indonesia: Pemenuhan Hak Asasi Manusia Dalam Negara Hukum,” Jurnal Supremasi Hukum 2, no. 2 (2013): 333-58.

${ }^{33}$ Santoso, Meyriswati, and Alfian, "Korupsi Dan Mentalitas: Kendala Kultural Dalam Pemberantasan Korupsi Di Indonesia."

${ }^{34}$ Satjipto Rahardjo, Ilmu Hukum (Bandung: Citra Aditya Bakri, 2000): 53.
} 
protect human rights that others have violated. This protection is provided to the community to enjoy all of the rights guaranteed by law. According to Philipus M. Hadjon, legal protection for the community includes both preventive and repressive legal protection. Preventive legal protection allows the public to submit objections or opinions before a decision is made, whereas repressive legal protection focuses on resolving disputes. ${ }^{35}$ Legal protections for citizens' rights in cases of corruption are implemented through both preventive and repressive measures. The public can notify the $K P K$ if there is a suspicion of corruption in preventive legal protection. In contrast, repressive forms of legal protection are carried out by forming legal rules with very severe penalties for corruptors and law enforcement that attempts to eradicate existing corruption cases.

Revrisond Baswir conveyed that the historical development of corruption in Indonesia was mainly related to power and the development of critical attitudes in society. Corruption will be perceived as extremely dangerous if the public becomes increasingly critical of corruption cases in Indonesia. Society can file a complaint against the state through its critical nature to protect its citizens' rights. The state must protect against corruption cases through preventive and repressive measures. In terms of preventive measures, the public can report a suspicion of a corruption case. The community plays a vital role in assisting existing law enforcement officials in uncovering corruption cases. The table below shows the number of public complaints received by the KPK.

Table. 3. Public Complaints on Corruption Cases in 2019

\begin{tabular}{|c|c|c|c|c|c|}
\hline Month & $\begin{array}{l}\text { Complaint } \\
\text { Received }\end{array}$ & $\begin{array}{c}\text { Complaint } \\
\text { Verified }\end{array}$ & Month & $\begin{array}{c}\text { Complaint } \\
\text { Received }\end{array}$ & $\begin{array}{c}\text { Complaint } \\
\text { Verified }\end{array}$ \\
\hline January & $\begin{array}{c}669 \\
\text { Complaints } \\
\end{array}$ & $\begin{array}{c}354 \\
\text { Complaints } \\
\end{array}$ & January & 669 Complaints & 354 Complaints \\
\hline February & $\begin{array}{c}508 \\
\text { Complaints } \\
\end{array}$ & $\begin{array}{c}257 \\
\text { Complaints } \\
\end{array}$ & February & 508 Complaints & 257 Complaints \\
\hline March & $\begin{array}{c}566 \\
\text { Complaints }\end{array}$ & $\begin{array}{c}285 \\
\text { Complaints }\end{array}$ & March & 566 Complaints & 285 Complaints \\
\hline April & $\begin{array}{c}494 \\
\text { Complaints }\end{array}$ & $\begin{array}{c}274 \\
\text { Complaints }\end{array}$ & April & 494 Complaints & 274 Complaints \\
\hline May & $\begin{array}{c}570 \\
\text { Complaints }\end{array}$ & $\begin{array}{c}291 \\
\text { Complaints }\end{array}$ & May & 570 Complaints & 291 Complaints \\
\hline June & $\begin{array}{c}347 \\
\text { Complaints }\end{array}$ & $\begin{array}{c}158 \\
\text { Complaints }\end{array}$ & June & 347 Complaints & 158 Complaints \\
\hline July & $\begin{array}{c}594 \\
\text { Complaints } \\
\end{array}$ & $\begin{array}{c}285 \\
\text { Complaints } \\
\end{array}$ & July & 594 Complaints & 285 Complaints \\
\hline August & $\begin{array}{c}566 \\
\text { Complaints }\end{array}$ & $\begin{array}{c}224 \\
\text { Complaints }\end{array}$ & August & 566 Complaints & 224 Complaints \\
\hline September & $\begin{array}{c}497 \\
\text { Complaints }\end{array}$ & $\begin{array}{c}186 \\
\text { Complaints }\end{array}$ & September & 497 Complaints & 186 Complaints \\
\hline October & $\begin{array}{c}385 \\
\text { Complaints }\end{array}$ & $\begin{array}{c}133 \\
\text { Complaints } \\
\end{array}$ & October & 385 Complaints & 133 Complaints \\
\hline November & $\begin{array}{c}490 \\
\text { Complaints }\end{array}$ & $\begin{array}{c}174 \\
\text { Complaints }\end{array}$ & November & 490 Complaints & 174 Complaints \\
\hline December & $\begin{array}{c}398 \\
\text { Complaints }\end{array}$ & $\begin{array}{c}158 \\
\text { Complaints }\end{array}$ & December & 398 Complaints & 158 Complaints \\
\hline
\end{tabular}

${ }^{35}$ Philipus M. Hadjon, Perlindungan Hukum Bagi Rakyat Di Indonesia (Surabaya: PT. Bina Ilmu, 1987): 5. 


\begin{tabular}{|c|c|c|c|c|c|}
\hline Amount & $\begin{array}{c}6084 \\
\text { Complaints }\end{array}$ & $\begin{array}{c}2780 \\
\text { Complaints }\end{array}$ & Amount & $\mathbf{6 0 8 4}$ Complaints & $\begin{array}{c}2780 \\
\text { Complaints }\end{array}$ \\
\hline
\end{tabular}

Source: KPK, “Laporan Tahunan KPK 2019”, op.cit, p. 119.

Based on the table above, the community's active role in uncovering corruption cases is part of the obligation to break the chain of corruption and fulfil citizens' rights to enforce the law. Max Weber introduced the concept of a verstehen approach to explaining the meaning of one's actions. The basic assumption of someone acting is that they are performing it and placing themselves in the environment of other people's thinking and behaviour. This concept leads to the motivation to achieve the goal (to motivate). ${ }^{36}$ It is clear from the public's participation in filing a complaint about a suspicion of corruption that not all were directly affected by the corruption case. Complaints are filed because they believe they will suffer the same fate as others in corruption cases. In Indonesia, the goal is to enforce the law and eradicate corruption.

Corruption has violated people's rights by stealing state funds that should have been used to improve welfare, education, and healthcare access. These funds are managed by law enforcement agencies such as the National Police, the Attorney General's Office, and the KPK. The government has provided a large budget for law enforcement officials to uncover corruption cases to eradicate corruption. The data's details are listed below.

Table. 4. Budget Allocation for Case Handling at the Probe/Investigation Level of Law Enforcement Officials

\begin{tabular}{|c|c|c|c|c|}
\hline \multicolumn{2}{|c|}{ Information } & National & Province & Regency/City \\
\hline \multirow{3}{*}{ Police } & Budget & $\begin{array}{c}\text { IDR 297,8 } \\
\text { Million/Case }\end{array}$ & $\begin{array}{c}\text { IDR 182 Million-1,3 } \\
\text { Billion/Case }\end{array}$ & $\begin{array}{c}\text { IDR 6,4 Million- } \\
\text { 543,2 Million/Case }\end{array}$ \\
\cline { 2 - 5 } & Target & 25 Cases & 2-47 Cases & 1-75 Cases \\
\hline \multirow{3}{*}{ Attorney } & Budget & $\begin{array}{c}\text { IDR 158,7 } \\
\text { Million/Case }\end{array}$ & $\begin{array}{c}\text { IDR 129.8 } \\
\text { million/case }\end{array}$ & $\begin{array}{c}\text { IDR 129.8 } \\
\text { million/case }\end{array}$ \\
\cline { 2 - 5 } & Target & 50 Cases & 1 Case & 1 Case \\
\hline \multirow{3}{*}{ KPK } & Budget & $\begin{array}{c}\text { IDR 244,5 } \\
\text { Million/Case }\end{array}$ & NA & NA \\
\cline { 2 - 5 } & Target & 120 Cases & & \\
\hline
\end{tabular}

Source: ICW, “Laporan Pemantauan Tren Penindakan Kasus Korupsi Semester I 2020”, p. 9.

The amount of budget allocated for disclosing corruption cases is leading the government to protect citizens' constitutional rights from the threat of corruption. Although the handling is still considered unsuccessful because many cases have not been revealed, the efforts made deserve to be recognised. There is a greater chance that corruption cases will be disclosed If law enforcement officers and the community work well together. The public outpouring of rage against corruption can be harnessed as a source of information for law enforcement officials. No matter how insignificant the information provided by the public is, it is hugely beneficial to eradicate corruption. Comprehensive community development is required so that a later participatory society can be accommodated and easier access to reporting for anyone. Eradicating corruption is such an important goal that it necessitates every individual and institution to contribute to its achievement.

36 Ida Bagus Wirawan, Teori-Teori Sosial Dalam Tiga Paradigma (Jakarta: Kencana Prenada Media Grup, 2012): 83 . 
Law enforcement officers are expected to find it easier to obtain information about corruption cases due to a participatory community. As the most vulnerable group in dealing with corruption cases, the state must establish legal instruments to protect people who report suspected corruption cases. There is a profound social structure that sees participatory societies as disruptive individuals. ${ }^{37}$ In the end, people will prefer to remain silent rather than speak out against corruption. Do not let community participation become a loss for the community, leading to individuals being reported to authorities under the guise of defaming certain people. The state must guarantee the protection of personal data and personal safety. ${ }^{38}$ This legal protection must be adequately implemented for community participation to run smoothly.

Several things must be done immediately to eradicate corruption, including legal protection and the fulfilment of citizens' rights must be high on the government's priority list. This is consistent with the Indonesian nation's goal of improving people's lives. State funds allocated for poverty alleviation, healthcare improvements, and education provision can be realised by eradicating corruption. As a result, it is hoped that the Indonesian nation's golden generation will be realised. There are several things that must be done immediately in eradicating corruption, including:

\section{a. The government should increase its support for anti-corruption education.}

Anti-corruption education seeks to form three aspects of the human psyche: cognitive, affective, and conative. All three must be viewed as a unified whole that influences one another. ${ }^{39}$ This anti-corruption education is expected to instil fundamental human values that will encourage anti-corruption behaviour in all individuals. Although every human being has a negative side, it is hoped that this anti-corruption character education will eliminate it and form positive human value. ${ }^{40}$ The expected outcome is that future generations will despise the existence of corruption and become a participatory society in eradicating corruption. This must be done not only in official schools but also in the social realm. Everyone can perpetuate corruption if they have a position and authority in it. Anti-corruption education must be broadened. Without waiting for a corruption case to occur first, taking preventive action is the greatest option.

\section{b. There is a need for public education on the reporting mechanism for possible corruption cases.}

The education can be accompanied by anti-corruption education in formal schools and the social sphere of society. Information on community reporting accommodations is not sufficient with only seminars in universities but must reach all levels of society. This will take

\footnotetext{
${ }^{37}$ Praise Juinta W. S. Siregar and Nikki Tirta, "Implementasi Stimulan Reward and Punishment Pada Kurikulum Pendidikan Antikorupsi,” Integritas: Jurnal Antikorupsi 6, no. 1 (2020): 153-68, https://doi.org/10.32697/integritas.v6i1.634.

${ }^{38}$ Marten Bunga et al., "Urgensi Peran Serta Masyarakat Dalam Upaya Pencegahan Dan Pemberantasan Tindak Pidana Korupsi," Law Reform 15, no. 1 (2019): 85-97, https://doi.org/10.14710/lr.v15i1.23356.

39 Sumaryati, Siti Murtiningsih, and Septiana Dwi Putri Maharani, "Penguatan Pendidikan Antikorupsi Perspektif Esensialisme," Integritas: Jurnal Antikorupsi $6, \quad$ no. $1 \quad$ (2020): 1-14, https://doi.org/10.32697/integritas.v6i1.408.

40 Power, Achievement, Hedonism, Stimulation, Self-direction, Universalism, Benevolence, Tradition, Conformity, and Security are among the ten fundamental human values described by Schwarz. These ten factors are the foundation of human behaviour and can encourage an individual to do something. See Shalom $\mathrm{H}$. Schwartz, "Are the Universal Aspects in the Structure and Contents of Human Values?," Journal of Social Issues 50, no. 4 (1994): 19-45, https://doi.org/10.1111/j.1540-4560.1994.tb01196.x. Yuwanto then classified the Corruptor Profile into five categories based on the review of Basic Human Values, including Tradition, Tradition Self Direction Stimulation, Self-Direction Stimulation Achievement Power, Conformity Security, and Hedonism Power. The five profiles become an individual's internal motivating factors for committing corruption. As a result, anti-corruption education must be capable of eradicating the negative aspects of Basic Human Value.
} 
some time in the early stages of implementation, but it will be a long-term benefit in eradicating corruption.

\section{c. The state must enact legal instruments that provide legal protection to those who assist in the abolition of corruption.}

This legal instrument can take the form of a revision of the law on the Eradication of Corruption Crimes and the Law on the Corruption Eradication Commission, at the very least.

\section{d. Appropriate law enforcement must be carried out.}

Character education for law enforcement officers is necessary to reduce actions that only benefit themselves personally and corruptors. So that law enforcement can serve the community and provide justice.

e. In circumstances of law enforcement against corruption, the highest penalty must be applied.

The goal is to serve as a deterrent to corruptors. Furthermore, it is hoped that irresponsible individuals will be afraid to commit corruption in the future.

\section{f. Rewarding law enforcement officers who report self-beneficial actions by other law} enforcement officers. ${ }^{41}$

The government should reward law enforcement officers who dare to report the actions of other officers. This is a form of appreciation in the fight against corruption. The problem of corruption cases will never be solved as long as law enforcement officials do not follow existing legal regulations. As a result, every law enforcement agency must be cleansed of irresponsible individuals.

\section{Conclusion}

Due to some of the problem in the discussions, the eradication of corruption cases in Indonesia can be less than optimal. The author views this problem as not a failure because many systematic efforts have been made to eradicate corruption. In the end, every element in the legal system in Indonesia has not been well correlated. The complexity of law enforcement in corruption cases raises public awareness of the need to participate in eradicating corruption. A participatory society is not the same as a legal culture. A participatory society is characterised by a high level of public awareness and a strong desire to enforce the law, whereas legal culture views society as a subject that must not violate the law. So that in enforcing the law in Indonesia, it can be formulated into four determining factors for its success, including a) Legal Substance; b) Legal Structure; c) Legal Culture; and d) Participatory Society. The determining factors are limited to law enforcement in corruption cases and law enforcement in general. These four factors are expected to work well in the future to uphold constitutional rights and provide justice and benefit to the community.

\section{Bibliography}

\section{A. Book}

Ali, Zainuddin. Metode Penelitian Hukum. Jakarta: Sinar Grafika, 2011.

Bahari, Adib, and Khotibul Umam. KPK: Komisi Pemberantasan Korupsi Dari A Sampai Z. Yogyakarta: Pustaka Yustisia, 2009.

Erwin, Muhammad. Filsafat Hukum Refleksi Kritis Terhadap Hukum. Jakarta: Rajawali,

\footnotetext{
${ }^{41}$ A. Mitchell Polinsky and Steven Shavell, "Corupption and Optimal Law Enforcement," , Journal of Public Economics 81, no. 1 (2001): 1-24, https://doi.org/10.1016/S0047-2727(00)00127-4.
} 
2013.

Friedman, Lawrence M. The Legal System: A Social Science Perspective. New York: Russel Sage Foundation, 1975.

Hadjon, Philipus M. Perlindungan Hukum Bagi Rakyat Di Indonesia. Surabaya: PT. Bina Ilmu, 1987.

Muladi, Muladi. Hak Asasi Manusia Hakekat, Konsep Dan Implikasinya Dalam Perspektif Hukum Dan Masyarakat. Bandung: Refika Aditama, 2009.

Rahardjo, Satjipto. Ilmu Hukum. Bandung: Citra Aditya Bakri, 2000.

Sabon, Max Boli. Hak Asasi Manusia: Bahan Pendidikan Perguruan Tinggi. Jakarta: Universitas Katolik Indonesia Atma Jaya, 2019.

Soekanto, Soerjono. Faktor-Faktor Yang Mempengaruhi Penegakan Hukum. Jakarta: UI Press, 1983.

Sunggono, Bambang. Metodologi Penelitian Hukum. Jakarta: Rajawali Press, 2015.

Ubaedillah, A. Pancasila Demokrasi Dan Pencegahan Korupsi. Jakarta: Prenadamedia Group, 2015.

Waluyo, Bambang. "Optimalisasi Pemberantasan Korupsi Di Indonesia." Jurnal Yuridis 1, no. 2 (2014): 169-82.

Wirawan, Ida Bagus. Teori-Teori Sosial Dalam Tiga Paradigma. Jakarta: Kencana Prenada Media Grup, 2012.

\section{B. Journal}

Ariyanti, Vivi. "Kebijakan Penegakan Hukum Dalam Sistem Peradilan Pidana Indonesia." Jurnal Yuridis 6, no. 2 (2019): 33-54. https://doi.org/10.35586/jyur.v6i2.789.

Asnawi, Habib Shulton. "Membongkar Paradigma Positivisme Hukum Dalam Pemberantasan Korupsi Di Indonesia: Pemenuhan Hak Asasi Manusia Dalam Negara Hukum." Jurnal Supremasi Hukum 2, no. 2 (2013): 333-58.

Benson, Bruce L. "Corruption in Law Enforcement: One Consequence of "The Tragedy of the Commons' Arrising with Public Allocation Processes." International Review of Law and Economics 8, no. 1 (1988): 73-84. https://doi.org/10.1016/0144-8188(88)90016-6.

Borja, Karla. "Corruption Indicators, Foreign Capital, and Economic Growth in Developing Countries." The Journal of Developing Areas 51, no. 4 (2017): 95-107. https://doi.org/10.1353/jda.2017.0090.

Bunga, Marten, Mustating Dg Maroa, Amelia Arief, and Hardianto Djanggih. "Urgensi Peran Serta Masyarakat Dalam Upaya Pencegahan Dan Pemberantasan Tindak Pidana Korupsi." Law Reform 15, no. 1 (2019): 85-97. https://doi.org/10.14710/lr.v15i1.23356.

Djafar, Wahyudi. "Menegaskan Kembali Komitmen Negara Hukum: Sebuah Catatan Atas Kecenderungan Defisit Negara Hukum Di Indonesia.” Jurnal Konstitusi 7, no. 5 (2010): 151-74.

Hikmah, Hikmah, and Eko Sopoyono. "Kebijakan Formulasi Sanksi Pidana Mati Terhadap Pelaku Tindak Pidana Korupsi Berbasis Nilai Keadilan.” Jurnal Pembangunan Hukum Indonesia 1, no. 1 (2019): 78-92. https://doi.org/10.14710/jphi.v1i1.78-92.

Isra, Saldi, Yuliandri, Feri Amsari, and Hilaire Tegnan. "Obstruction of Justice in the Effort to Eradicate Corruption in Indonesia." International Journal of Law, Crime, and Justice 51 (2017): 72-83. https://doi.org/10.1016/j.ijlcj.2017.07.001.

Kartika, Epa, Rizky Nugraha Murnawan, and Agung Budiono. "Peran Masyarakat Sipil Dalam Pemberantasan Korupsi Sektor Sumber Daya Alam." Integritas: Jurnal Antikorupsi 5, no. 2 (2019): 93-106. https://doi.org/10.32697/integritas.v5i2-2.485.

Mapuasari, Supeni Anggraeni, and Hadi Mahmudah. "Korupsi Berjamaah: Konsensus Sosial Atas Gratifikasi Dan Suap." Integritas: Jurnal Antikorupsi 4, no. 2 (2018): 159-76. https://doi.org/10.32697/integritas.v4i2.279. 
Mawarini Sukmariningsih, Retno. "Penataan Lembaga Negara Mandiri Dalam Struktur Ketatanegaraan Indonesia." Mimbar Hukum - Fakultas Hukum Universitas Gadjah Mada 26, no. 2 (2014): 194-204. https://doi.org/10.22146/jmh.16039.

Nurudin, Agus. "Upholding the Impartiality of Judges in Judicial System." Hasanuddin Law Review 6, no. 1 (2020): 80-88. https://doi.org/10.20956/halrev.v6i1.2268.

Pertiwi, Kanti. "Kesenjangan Dalam Wacana Antikorupsi Di Indonesia: Temuan Dari Literatur Studi Korupsi Kritis.” Integritas: Jurnal Antikorupsi 5, no. 2 (2019): 133-50. https://doi.org/10.32697/integritas.v5i2.475.

Polinsky, A. Mitchell, and Steven Shavell. "Corupption and Optimal Law Enforcement." , Journal of Public Economics 81, no. 1 (2001): 1-24. https://doi.org/10.1016/S00472727(00)00127-4.

Pramono, Agus. "Kekuasaan Dan Hukum Dalam Perkuatan Pemberantasan Korupsi." Jurnal $M M H 42$, no. 1 (2013): 105-13.

Ramadani, Rizki. "Reformulation of Institutional Relationship between the People's Representative Council and the Corruption Eradication Commission." Corruptio 2, no. 1 (2021): 33-44. https://doi.org/10.25041/corruptio.v2i1.2264.

Santoso, Listiyono, Dewi Meyriswati, and Ilham Nur Alfian. "Korupsi Dan Mentalitas: Kendala Kultural Dalam Pemberantasan Korupsi Di Indonesia." Jurnal Masyarakat, Kebudayaan Dan Politik 27, no. 4 (2014): 173-83. https://doi.org/10.20473/mkp.V27I42014.173-183.

Schwartz, Shalom H. "Are the Universal Aspects in the Structure and Contents of Human Values?" Journal of Social Issues 50, no. 4 (1994): 19-45. https://doi.org/10.1111/j.1540-4560.1994.tb01196.x.

Siregar, Praise Juinta W. S., and Nikki Tirta. "Implementasi Stimulan Reward and Punishment Pada Kurikulum Pendidikan Antikorupsi." Integritas: Jurnal Antikorupsi 6, no. 1 (2020): 153-68. https://doi.org/10.32697/integritas.v6i1.634.

Sriwidodo, Joko. "Changes in Corruption Eradication Commission in Legal Sociology $\begin{array}{lllll}\text { Perspective." } \quad \text { Corruptio } & 1, \quad \text { no. } & 1 & \text { (n.d.): }\end{array}$ https://doi.org/10.25041/corruptio.v1i1.2073.

Sumaryati, Siti Murtiningsih, and Septiana Dwi Putri Maharani. "Penguatan Pendidikan Antikorupsi Perspektif Esensialisme.” Integritas: Jurnal Antikorupsi 6, no. 1 (2020): 114. https://doi.org/10.32697/integritas.v6i1.408.

Wicipto Setiadi. "Korupsi Di Indonesia (Penyebab, Bahaya, Hambatan Dan Upaya Pemberantasan, Serta Regulasi).” Jurnal Legislasi Indonesia. Accessed April 26, 2021. https://e-jurnal.peraturan.go.id/index.php/jli/article/view/234.

\section{Regulation}

Constitutional Court Decision Number 70/PUU-XVII/2019.

Constitutional Court Decision Number 71/PUU-XIV/2016.

Law Number 10 of 2016 Concerning Second Amendment to Law Number 1 of 2015 concerning Stipulation of Government Regulations in Lieu of Law Number 1 of 2014 Concerning the Election of Governors, Regents and Mayors into Law.

Law Number 19 of 2019 Concerning the Second Amendment to Law Number 30 of 2002 Concerning the Corruption Eradication Commission.

Law Number 20 of 2001 Concerning Amendments to Law Number 31 of 1999 Concerning Eradication of Criminal Acts of Corruption.

PKPU Number 18 of 2019 concerning the Second Amendment to PKPU Number 3 of 2017 Concerning Nominations for the Election of Governor and Deputy Governor, Regent and Deputy Regent, and Mayor and Deputy Mayor.

The 1945 State Constitution of the Republic of Indonesia. 


\section{Internet}

Cody, John Joseph. "A Study of the Theory and Practice of Effective Law Enforcement". Master's Theses, Paper 1556, (1960). Retrieved 15 May 2021, from https://ecommons.luc.edu/luc_theses/1556

ICW. "Laporan Pemantauan Tren Penindakan Kasus Korupsi Semester I 2020". Retrieved 24 April 2021, from https://antikorupsi.org

KPK. “Laporan Tahunan KPK 2019”. Retrieved 24 April, 2021, from https://www.kpk.go.id/ 